\title{
ACTUAL PROBLEMS OF BUSINESS RISK IN SME SEGMENT. CASE STUDY FROM SLOVAKIA
}

\author{
Jaroslav BELÁS, ${ }^{2}$ Yuriy BILAN, ${ }^{3}$ Aleksandr KLJUČNIKOV, ${ }^{4}$ Zuzana \\ VINCÚROVÁ, Jiř́ MACHÁČCEK
}

\begin{abstract}
The aim of this article was to define, quantify and compare the significant attributes of business risk for small and medium-sized enterprises (SMEs) in the selected regions of Slovakia. The data was collected through a questionnaire. The whole research was conducted in the Bratislava region on a sample of 102 SMEs, in the region of Trencin on a sample of 105 SMEs and in the Zilina region on a sample of 168 SMEs. Thus we compared important factors of business risk in the most economically developed region of the Slovak capital to the average regions of Trencin and Zilina. On the basis of the results of our research, we can conclude that the most important business risk is market risk in all regions. The average value of perceived market risk was higher than 50\%. For this reason entrepreneurs have indicated the existence of negative trends in performance and profitability of their companies.
\end{abstract}

\section{KEY WORDS}

Small and medium-sized enterprises, regional differences, business risk, market risk

\section{JEL CLASSIFICATION}

G L26, R11

\footnotetext{
2 Correspondence address: prof. Ing. Jaroslav Belás, PhD., Department of Enterprise Economics, Faculty of Management and Economics, Tomas Bata University in Zlin, Mostní 5139, 76001 Zlin, Czech Republic; email: belas111@gmail.com

${ }^{3}$ Correspondence address: Dr. Yuriy Bilan, University of Szczecin, Faculty of Economics Science and Management, Microeconomics Department, e-mail: yuriy_bilan@yahoo.co.uk

${ }^{4}$ Correspondence address: Ing. Aleksandr Ključnikov, Ph.D. aleksandr.kljucnikov@vsp.cz, Vysoká škola podnikání, Michálkovická 1810/181, 71000 Ostrava-Slezská Ostrava; www.vsp.cz

${ }^{5}$ Correspondence address: Ing. Zuzana Vincúrová, PhD., Faculty of Economics and Business, Pan-Europan University, Tematinska 10, 85105 Bratislava, Slovak Republic, email: zuzana.vincurova@ paneurouni.com

${ }^{6}$ Correspondence address: Ing. Jiří Macháček, Department of Regional Development, Public Sector Administration and Law, Faculty of Management and Economics, Tomas Bata University in Zlin, Mostní 5139, 76001 Zlin, Czech Republic; email: machacek@fame.utb.cz
} 


\section{INTRODUCTION}

Small and medium-sized enterprises (SMEs) have become an increasingly important component of economic development representing a substantial proportion of the national economies all around the world (Karpak and Topcu, 2010). In this context, Henderson and Weiler (2010) indicate that SME can be characterized as major engine of economic growth.

SMEs have specific features and fulfil important tasks in an economic system. SMEs, which clearly dominate in terms of their number in any economic system, contribute significantly to higher employment and the GDP, help to create more intensely competitive environment which has a great importance in relation to prices and quality of products and services. It is evident that SMEs have a negative impact on unemployment rates.

Entrepreneurship in segment of SMEs represents the actual and interesting area of theoretical research and practical applications.

In this article there are examined business risks and changes that have occurred in this area field after the economic crisis in the economic system of Slovakia.

\section{IMPORTANT ATTRIBUTES OF BUSINESS RISK IN SME SEGMENT}

Business risk could be defined as an option (uncertainty), that actual business results achieved would deviate from the results assumed, and furthermore these variations may be (Hnilica, Fotr, 2009): desirable (towards higher profits), or undesirable (towards loss); different sizes from small deviations when the results are close to those planned, up to a large extent of deviations (significant business success in case of desired deviation or significant financial difficulties and bankruptcy in case of adverse deviations).

Risks that are specific for small businesses according to the Risk Management Guide for Small Businesses processed by the organization of Global Risk Alliance:

- Financial risks - are associated with management of the cash flow, receivables and payables, taxes, budgetary requirements and others,

- Organizational risks - are associated with the insuring of internal organizational needs of the company whether they be cultural issues, structural or human,

- Legal risks - are related to compliance with applicable legal standards in the country,

- Operational risks - are associated primarily with planning, operational activities, resources and mutual cooperation between the different functional areas of the enterprise,

- Market, business risks - are associated with placing the product on the market, with the business growth, commercial success, lifetime of the product or service, the service and etc.,

- Security risks - are associated with compliance with the safety and health at work in a given subject, security has a range from the individual level, through a public safety to security products in the enterprise,

- Strategic risks - are associated with the identifying and securing of appropriate business strategy from the very identification and evaluation of opportunities through decisionmaking to determine the long-term strategic objectives,

- Technical risks - are related to the operation of all machinery and equipment that the enterprise uses in its business activities, in particular the maintenance, renewal, safety assessment and depreciation,

- Criminal risks - are associated with ensuring of security of commercial premises, property and persons, information, technology and so on, 
- Reputation risks - are associated with securing and maintaining of corporate reputation,

- Service risks - are associated with provision of additional services to the customer; in particular, the after sales service, product quality, customer communication,

- Project risks - are associated with the preparation and actual implementation of projects in various fields,

- Risks of the management of interested parties - are the risks that include identification, establishment and maintenance of appropriate relationships between internal and external interested parties,

- Technological risks - are related to the implementation, management, maintenance and renewal of technologies used by the business company. (Risk management guide for small businesses, 2005)

Sources of the business management risks can be briefly summarized into the following areas: improper changes in the management system; lack of strategic focus of the company, respectively insufficient support of strategic thinking; inability to predict the development of an external environment; poor quality of planning; insufficient monitoring of implementation, results and impacts; lack of management skills (professional, conceptual); poor flexibility in decision-making (wrong decisions due to lack of necessary information); increasing of centralization of decisionmaking; poor interpersonal relationships in the workplace; communication problems between coworkers and management; unclear definition of competence and responsibilities; inadequate reporting arrangements (reporting); lack of interest by the staff and the failure to address complaints; poor cooperation between the business units, and failure to use real development potential. (Hudákova, In Belás et al., 2014 a)

In 2013 the Association for Financial Professionals in cooperation with Zanders Treasury and Finance Solutions held an international survey called „Treasury Risk Survey“ that was focused on global trends in the corporate risk management. According to that survey the European companies consider as the most threat to their business the following risks (CFO, 2013): liquidity risk, exchange rate risk, and reputational risk.

Particularly important issue of SMEs is a financial gap because many of these companies have a very limited access to an external financing. Even before the economic downturn, some of the small businesses had troubles with making funds necessary for growth and innovation available for them. Due to the financial crisis, banks are even less willing to lend to companies in many countries, which further exacerbated problems that companies are facing already. (European Commission, 2011)

In this context Dierkes, Erner, Langer and Norden (2013), state that companies in the segment of SMEs are smaller, more informational opaque, riskier, and more dependent on trade credit and bank loans. According to Canales and Nanda (2012) small businesses, and particularly young small businesses, have little internal cash flow to finance their operations and are also associated with significant asymmetric information.

Di Giuli, Caselli and Gatti (2011) state that for small and medium enterprises credit availability is a very important element for their development. Covaci (2008) adds that SMEs are perceived as being more risky than big companies, because they present a high sensitivity to economic shocks while disposing of an inferior capacity to absorb variations.

Neuberger a Räthke (2009) report, that small firms are characterized by higher information asymmetry and credit risk. This point of view is also supported by Kirschenmann and Norden 
(2012). In this context Fidrmuc and Hainz (2010) state that the major factors for SMEs default are classified according to high indebtedness, low profit, and low liquidity.

According to Fetisovová, Vlachynský, and Sirotka (2004) and The Business risks (2013), among the basic business risks of SMEs it can be included limited access to loans, small capital strength, increased competition, high tax burden, low level of managerial skills, low level of diversification, administrative complexity, risk of failure, relationship between work and private life.

According to Fetisovová et al. (2012), financial and economic crisis had serious implications on the performance of small and medium-sized companies in the European Union. Gross production of SMEs within countries of EU27 by 5,5\% in 2009 was decreased. Insufficient effective demand was the most urgent issue for $29 \%$ of these SMEs. Authors report that the demand on domestic markets of E27 will continue to be weak. The approach to financial resources for SMEs represents a serious problem for these companies. However, in the short term, it is less urgent than lack of demand on the domestic market.

\section{RESEARCH OBJECTIVES AND USED METHODOLOGY}

The aim of this article was to define, quantify and compare the significant attributes of business risk for small and medium-sized enterprises in the selected regions of Slovakia.

The research on business environment was conducted in 2013 in the selected regions of Slovakia through a questionnaire survey. In the Bratislava region (BA) 102 SMEs have been reached; in the Zilina region (ZA) 164 SMEs have been reached; in the Trencin region (TN) 105 SMEs have been reached. Companies' data was provided by their owners.

These regions have been chosen because it enables us to compare business environment in the most economically developed region to the averagely developed regions. Our aim was to measure the differences among these regions and to define their significance.

The Bratislava region is located in the west and southwest part of Slovakia. It has an area of 2,053 $\mathrm{km}^{2}$ which means it is the smallest region of Slovakia. The number of inhabitants was 628,686 and the unemployment rate was $5.4 \%$ in 2011. The Bratislava region is the region with the best economic performance and creates $26 \%$ of the total Slovak GDP. The economy of the Bratislava region contains all the economic sectors based on the traditional industrial production of goods. The most important industrial sectors there are the chemical, automotive, electronic and food industry and the mechanical engineering. Over the last few years, the Bratislava region has become a European centre of automotive industry representing $30 \%$ of the overall Slovak export. (Bratislava region, 2014)

The Trencin region has an area of $4,502 \mathrm{~km}^{2}$, has about 600,000 inhabitants, the GDP per capita reached 10,744 EUR in 2010, the registered unemployment rate was at $10.89 \%$ in 2012 (significantly below the overall Slovak average of $14.44 \%$ ).

The Zilina region has an area of $6,800 \mathrm{~km}^{2}$. Total population is up to 700,000 and the population density is 102 inhabitants per $\mathrm{km}^{2}$. The unemployment rate was raised to $11.91 \%$ in 2011 . The GDP per capita was 10,794 EUR in 2011.

In our research in the Bratislava region, the largest share of surveyed companies was comprised of SMEs operating in trade activities (33\%), followed by construction firms (12\%), manufacturing companies $(7 \%)$, transport companies $(1 \%)$ and agricultural enterprises $(1 \%)$. The remaining share was formed by companies operating in other sectors. 
In the Trencin region, the structure of companies was as follows: manufacturing companies (21\%), trade companies $(21 \%)$, construction companies (18\%), transport companies (4\%) and agricultural firms $(5 \%)$. The largest portion of companies operated in other sectors $(31 \%)$.

In the Zilina region, the structure of companies was as follows: $17 \%$ of companies operated in the manufacturing sector, $21 \%$ in the trade sector, $17 \%$ in the construction sector, $6 \%$ in the transport sector, $1 \%$ in the agricultural sector. The largest portion of companies operated in other sectors $(38 \%)$.

From the total number of 102 surveyed firms in the Bratislava region, 54\% of them were doing business more than 10 years, 19\% of them between 5 and 10 years, $27 \%$ of them between 1 and 5 years. Therefore it can be stated that the research was examining quite experienced entrepreneurs from this region. The size structure of companies was as follow: $83 \%$ were micro-enterprises, $12 \%$ were small enterprises and 5\% were medium-sized companies.

From the total number of 105 surveyed companies in the Trencin region, 54\% of companies do their business more than 10 years, $25 \%$ do their business from 5 to 10 years and $21 \%$ do their business from 1 to 5 years. The size structure of the companies was as follows: $62 \%$ were micro-enterprises, $31 \%$ were small enterprises and $7 \%$ were medium-sized enterprises.

In the Zilina region, of 164 surveyed companies $38 \%$ do business more than 10 years, 32\% represents firms which do their businesses from 5 to 10 years and $30 \%$ of surveyed companies do businesses from 1 to 5 years. Thus companies surveyed in this region were equally distributed from the perspective of business duration. As for the size structure, $66 \%$ was represented by micro enterprises, $20 \%$ were small companies and $14 \%$ were medium-sized enterprises.

In line with the findings of previous research, we hypothesize the following:

H1: The most important business risk at the moment is market risk. There are no regional differences in the perception of market risk.

$\mathrm{H} 2$ : An average value of the perceived market risk in all regions is higher than $50 \%$.

H3: The economic crisis has reduced the performance of SMEs in Slovakia by at least $15 \%$. There are no regional differences in the structure of the responses of entrepreneurs.

H4: The economic crisis has reduced the profitability of SMEs in Slovakia by at least $10 \%$. There are no regional differences in the structure of the responses of entrepreneurs.

In this article there was used Pearson's chi-square to determine whether there are statistically significant deviations between the compared data sets and theoretical frequencies.

Chi - square (good correlation test) is defined as follows. In scientific research there is tested the hypothesis $\mathrm{H}_{0:} \pi_{\mathrm{i}}=\pi_{\mathrm{i}}, 0$, where $\mathrm{i}=1,2, \ldots, \mathrm{K}$ ( $\mathrm{K}$ is the number of categories) and $\sum \pi \mathrm{i}_{, 0}=1$, against the alternative hypothesis $\mathrm{H}_{1}: \mathrm{H}_{0}$ is not applicable. Unless constants $\pi_{\mathrm{i}}, 0$ are equal, then the null hypothesis can be expressed as $\mathrm{H}_{0}: \pi_{1}=\pi_{2}=\ldots=\pi_{\mathrm{k}}$. For $\mathrm{n} \pi_{\mathrm{i}, 0} \geq 5$ is used Chi - square statistic given by the relationship

$$
\chi^{2}=\sum_{i=1}^{K} \frac{(n i-n \pi i, 0) 2}{n \pi i, 0},
$$

where $n \pi_{i, 0}$ is the theoretical (expected) occupation of the $\mathrm{i}$-th category in the selection of the range of $\mathrm{n}$. This random variable assumes that the hypothesis $\mathrm{H}_{0}$ is valid, $\mathrm{Chi}$ - square distribution with $(\mathrm{K}$ -1) degree of freedom, ie $\chi^{2}{ }^{n} \chi^{2[\mathrm{k}-1]}$. The calculated of the given value of the test criterion of $\chi^{2}$

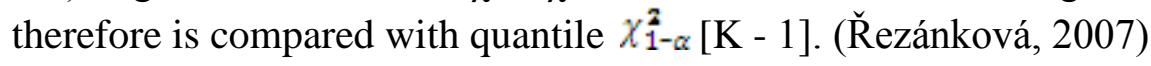


In the calculations of the Chi-square and p-value there was used a freely accessible calculator that is available at: http://www.socscistatistics.com/tests/chisquare2/Default2.aspx.

For the detection of statistically significant differences in the answers to each question there was used a Z-test available at: http://www.socscistatistics.com/tests/ztest/Default2.aspx.

\section{RESULTS AND SHORT DISCUSSION}

The perception of business risks and their intensity in the Slovak Republic are shown in Table 1.

\section{Table 1. Business risks and their intensity in the Slovak Republic}

\begin{tabular}{|c|c|c|c|c|}
\hline $\begin{array}{l}\text { You are facing many } \\
\text { risks in your job. } \\
\text { Which of them do you } \\
\text { consider as the key } \\
\text { ones? } \\
\text { Please select maximum } \\
\text { of three answers }\end{array}$ & BA & $\mathrm{TN}$ & $\mathrm{ZA}$ & $\begin{array}{c}\text { p-value****: } \\
\text { BA:TN/BA:ZA/TN:ZA }\end{array}$ \\
\hline $\begin{array}{l}\text { 1. Market risks (lack of } \\
\text { contracts) }\end{array}$ & $82 * / 56.58 * *$ & $87 * / 53.27$ & $132 * / 51.30$ & $0.6455 / 0.9840 / 0.6241$ \\
\hline $\begin{array}{l}\text { 2. Financial risk (poor } \\
\text { access to financing) }\end{array}$ & $55 / 31.94$ & $53 / 30,10$ & $96 / 32.95$ & $0.6171 / 0.4593 / 0.1936$ \\
\hline $\begin{array}{l}\text { 3. Operational risk } \\
\text { (inability to handle } \\
\text { processes) }\end{array}$ & $21 / 24.17$ & $15 / 20.71$ & $37 / 30.09$ & $0.2301 / 0.7039 / 0.0930$ \\
\hline $\begin{array}{l}\text { 4. Personnel risk (poor } \\
\text { staff) }\end{array}$ & $42 / 30,77$ & $50 / 31.04$ & $63 / 30.89$ & $0.3524 / 0.6527 / 0.1362$ \\
\hline 5. Legal risk & $17 / 32.01$ & $34 / 37.50$ & $61 / 28.76$ & $\mathbf{0 . 0 0 8 8 / 0 . 0 0 0 3 / 0 . 4 1 7 9}$ \\
\hline $\begin{array}{l}\text { 6. Security risk } \\
\text { (accidents, incidents, } \\
\text { etc.) }\end{array}$ & $30 / 28.76$ & $29 / 20.28$ & $54 / 24.73$ & $0.7718 / 0.5485 / 0.3576$ \\
\hline Chi-square/p-val & & & \multicolumn{2}{|c|}{\begin{tabular}{|r|}
$3.3572 / 0.4999 / / 4.6734 / 0.3225 / /$ \\
$4.8723 / 0.3007$ \\
\end{tabular}} \\
\hline
\end{tabular}

Notes: * means the number of respondents, $* *$ means the average impact of perceived risk, $* * *$ this chi-square and pvalue compares the structure of all responses, i.e. it examines if there are significant differences within the regions concerning all answers, ${ }^{* * * *}$-value compares the structure of the answer in each individual row by using the Z-score method, BA-Bratislava region, TN-Trencin region, ZA-Zilina region.

The Hypothesis 1 was confirmed. In our research it was found out that the most important business risk at the moment is market risk. Based on our own calculations, it was found out that there are regional differences in the perception of market risk. This fact was confirmed by the value of the test criteria $(\mathrm{p}$-value $=0.6455 / 0.9840 / 0.6241)$

At the same time, it was found out that there are no statistically significant differences in the structure of assessed risks in individual regions, which was confirmed by the values of the test criteria ( $p$-value $=0.4999 / 0.3225 / 0.3007)$.

The Hypothesis 2 was also confirmed. It was found out that the average value of perceived market risk in all regions is higher than $50 \%$. Paradoxically, the highest intensity of perceived market risk was found in Bratislava region, which can be considered to be the most economically developed. 
One possible explanation is that most probably in this region the entrepreneurs feel a stronger competition, which in their perception may be converted to a higher degree of market risk.

The most important business risks which were perceived by entrepreneurs in the Czech Republic were as follows: market, financial and personnel risks. Market risk was identified as a key risk by the largest number of entrepreneurs, that means $79.44 \%$ of them in the Czech Republic (Belás et al., 2014 b)

In Table 2 there are presented the results of research on the decline in performance of SMEs in Slovakia compared to the pre-crisis period.

Table 2. Decline in performance of SMEs in Slovakia

\begin{tabular}{|l|r|r|r|r|}
\hline $\begin{array}{l}\text { By what percentage your } \\
\text { current performance has } \\
\text { been decreased compared } \\
\text { to the pre-crisis period? }\end{array}$ & BA & TN & ZA & $\begin{array}{c}\text { p-value**: } \\
\text { BA:TN/BA:ZA/TN:ZA }\end{array}$ \\
\hline 1. up to 10\% & 23 & 20 & 28 & $0.5485 / 0.2077 / 0.5619$ \\
\hline 2. from 11 to 20\% & 11 & 12 & 33 & $0.8493 / \mathbf{0 . 0 4 4 4 / 0 . 0 6 8 8}$ \\
\hline 3. from 21 to 30\% & 18 & 22 & 34 & $0.4902 / 0.5687 / 0.8337$ \\
\hline 4. from 31 to 40\% & 9 & 14 & 9 & $0.2731 / 0.2627 / \mathbf{0 . 0 1 6 8}$ \\
\hline 5. from 41 to 50\% & 5 & 3 & 11 & $0.4533 / 0.5687 / 0.1802$ \\
\hline $\begin{array}{l}\text { 6. Other answers (over } \\
\text { 50\%, performance } \\
\text { increased, I haven't done } \\
\text { business) }\end{array}$ & 32 & 34 & 49 & $0.8729 / 0.7949 / 0.6672$ \\
\hline $\begin{array}{l}\text { The average value of } \\
\text { decline of performances in } \\
\%\end{array}$ & 18.73 & 17.45 & 18.78 & - \\
\hline \multicolumn{1}{|c|}{ Chi-square /p-value* BA:TN/ BA:ZA/TN:ZA } & & & \\
\hline
\end{tabular}

Notes: *this chi-square and p-value compares the structure of all responses, i.e. it examines if there are significant differences within the regions concerning all answers, **p-value compares the differences in structure of the answers in each individual row by using the Z-score method.

The Hypothesis 3 was partially confirmed. It was found out that compared with pre-crisis period, the performance of SMEs in Slovakia have decreased by at least $15 \%$. At the same time, it was found out that there are regional differences in the structure of the responses of the businessmen in Trncin and Zilina regions ( $\mathrm{p}$-value=0.0420). Our results suggest that there are some differences in the structure of responses of entrepreneurs, for example businessmen in the Žilina region compared with entrepreneurs in the Bratislava region significantly more reported that their performance is reduced in the range of $11-20 \%$ (p-value $=0.0444)$. Similarly, the entrepreneurs in the Trencin region compared with the entrepreneurs in the Zilina region statistically significantly more frequently reported that their performance is reduced in the range of $31-40 \%$.

Average performance decrease is represented by $15.80 \%$ in the Czech Republic in the same period. (Belás et al., 2014 b)

In Table 3 there are shown the results of our research in profitability of SMEs in Slovakia. 
Table 3. The decline in profitability of SMEs in Slovakia

\begin{tabular}{|c|c|c|c|c|}
\hline $\begin{array}{l}\text { How your company's } \\
\text { profitability has changed } \\
\text { compared to the pre-crisis } \\
\text { period? }\end{array}$ & $\mathrm{BA}$ & $\mathrm{TN}$ & $\mathrm{ZA}$ & $\begin{array}{c}\text { p-value**: } \\
\text { BA:TN/BA:ZA/TN:ZA }\end{array}$ \\
\hline $\begin{array}{l}\text { 1. Significantly decreased } \\
\text { (more than 20\%) }\end{array}$ & 31 & 32 & 43 & $0.9920 / 0.4593 / 0.4473$ \\
\hline $\begin{array}{l}\text { 2. Slightly decreased }(0- \\
20 \%)\end{array}$ & 28 & 38 & 61 & $0.1770 / 0.1010 / 0.8650$ \\
\hline 3. Is stable & 28 & 20 & 35 & $0.1527 / 0.2543 / 0.6455$ \\
\hline $\begin{array}{l}\text { 4. Slightly increased }(0- \\
20 \%)\end{array}$ & 7 & 7 & 21 & $0.9522 / 0.1236 / 0.1074$ \\
\hline $\begin{array}{l}\text { 5. Significantly increased } \\
\text { (more than 20\%) }\end{array}$ & 5 & 4 & 4 & $0.6965 / 0.2801 / 0.5157$ \\
\hline $\begin{array}{l}\text { 6. I was not doing business } \\
\text { before the crisis }\end{array}$ & 0 & 3 & 0 & - \\
\hline $\begin{array}{l}\text { The average value of the } \\
\text { decline in profitability in } \\
\%\end{array}$ & 11.76 & 14.31 & 12.01 & - \\
\hline \multicolumn{3}{|c|}{ Chi-square* /p-value* BA:TN/ BA:ZA/TN:ZA } & \multicolumn{2}{|c|}{$\begin{array}{r}2.9558 / 0.5653 / / 6.3969 / 0.1714 / / \\
3.2542 / 0.5162\end{array}$} \\
\hline
\end{tabular}

Notes: *this Chi-square and p-value compares the structure of all responses, i.e. it examines if there are significant differences within the regions concerning all answers, **p-value compares the differences in structure of the answers in each individual row by using the $\mathrm{Z}$-score method.

The Hypothesis 4 was confirmed. The economic crisis has reduced the profitability of SMEs in Slovakia by at least $10 \%$. At the same time, it was found out that there are no regional differences in the structure of the responses of the businessmen ( $\mathrm{p}$-value $=0.5653 / 0.1714 / 0.5162)$.

For comparison purpose there could be mentioned, that in the same time in the Czech Republic the average decrease in the profitability amounted in 10.44\% (Belás et al., $2014 \mathrm{c}$ )

The worsened conditions for business for SMEs have gradually transformed into tightening approach of commercial banks to finance these companies.

The global financial crisis has caused considerable concerns about what the banks' practices will be in relation to the loan financing of the corporate sector. The current signals confirm that banks in the Czech Republic and Slovakia have tightened the conditions for their clients. (Geršl and Jakubík, 2011)

Within our research, we asked entrepreneurs how the lending policies of commercial banks have changed compared to the pre-crisis period. $36.28 \%$ of the Bratislava region entrepreneurs stated the approach of banks has worsened compared to 2008 and only $8.82 \%$ stated the approach has improved. $14.71 \%$ of them declared no difference in the approach and $40.20 \%$ could not answer this question. Similar results were obtained in the other two regions. $47.62 \%$ of the Trencin region entrepreneurs stated the approach has worsened, whereas $11.43 \%$ stated the approach has improved. $31.10 \%$ of entrepreneurs in the Zilina region declared a worse attitude of banks and $12.20 \%$ of them a better commercial banks' attitude compared to 2008. These findings are compatible with the studies of the European Commission (2011), Di Giuli, Caselli and Gatti (2011), Dierkes, Erner, Langer and Norden (2013), and Kirschenmann and Norden (2012).

In this context Canton, Grilo, Monteagudo, and Zwan (2013) state better accounting information, firm size and firm age found a positive relationship for getting a bank loan. Psillaki, Tsolas, and 
Margaritis (2010) state that the company performance is negatively related to default. They have also shown that, firm efficiency has enough explanatory power to perform better than the financial indicators.

Generally, Slovak entrepreneurs evaluate the approach of the State to their needs and interests negatively. For instance, the Business Environment Index in relation to Slovakia, which is prepared by the Business Alliance of Slovakia, fell in 2011 to the historically lowest level since 2001 (Business Alliance of Slovakia, 2012).

Business environment in Slovakia was negatively perceived by $56 \%$ of companies in 2013. This results from the economic survey of the Slovak Chamber of Commerce (2014) among its members, which regularly takes place at the end of the year. A positive evaluation was showed only by $2 \%$ of respondents and the remaining $42 \%$ declared that the business environment has not changed compared since 2012. The national economic policy was negatively rated by $44 \%$ of respondents, while in the year on year comparison, negative evaluations decreased by 6 percentage points. Only $4 \%$ of business entities perceived the government measures as positive and nearly a half, namely $48 \%$, assessed the economic policy neutrally. More than $38 \%$ of respondents suggested to the government taking actions in the field of tax burden and reducing administrative burden. Participants in the survey suggested, for example, returning to a flat rate of income tax, reducing the rates of Value Added Tax, or taking effective measures against tax evasion. Approximately 33\% of business subjects required fundamental improvements in law enforcement and taking measures to accelerate solutions of commercial disputes. The greatest risks to businessmen were the following: high tax burden, poor law enforcement or cronyism and corruption in public procurement (Slovak Commercial and Industrial Chamber, 2014).

Despite these facts, the entrepreneurs in our research have showed large dose of business optimism. In the Bratislava region, up to $90 \%$ of entrepreneurs stated that they believed that their company will survive in next five years in surveyed research. This share was represented by $90 \%$ in Trencin region and Zilina region.

\section{CONCLUSIONS}

The aim of this article was to define, quantify and compare the significant attributes of business risk for small and medium-sized enterprises in the selected regions of Slovakia.

Our research showed there are few regional variations in the assessment of important attributes of business risk in the SMEs segment in Slovakia.

In our research it was found out that the most important business risk at the moment is market risk. Based on our own calculations, it was found out that there are no regional differences in the perception of market risk.

It was found out that in comparison with pre-crisis period, the performance of SMEs in Slovakia decreased by at least $15 \%$. At the same time, it was found that there are some regional differences in the structure of the responses of the businessmen in Slovakia.

The economic crisis has reduced the profitability of SMEs in Slovakia. At the same time, it was found that there are no regional differences in the structure of responses of Slovakian entrepreneurs. 
Although it is clear that there are certain limitations to our research (e.g. the number of companies involved into the research), it is expected our article has brought significant incentives for the formation of business environment in Slovakia.

Our future research will focus on examination of the relationships among personal characteristics of entrepreneurs, the propensity to risk and their financial performance.

\section{REFERENCES}

Belás, J. et al. (2014a) Podnikatel'ské prostredie malých a stredných firiem v Českej a Slovenskej republike. Žilina: Georg

Belás, J. et al. (2014b) Business risks and the level of entrepreneurial optimism of SME in the Czech and Slovak Republic. Journal of competitiveness, 6(2): 30 - 41.

Belás, J. et al. (2014 c) Significant attributes of the business environment in Small and mediumsized enterprises. Economics \& Sociology, 7(3): 13 - 28.

Bratislavský samosprávny kraj. (2014) Informácie o kraji. Retrieved from http://www.regionbsk.sk/clanok/informacie-o-kraji-126328.aspx

Canales, R., Nanda, R. (2012) A darker side to decentralized banks: Market power and credit rationing in SME lending. Journal of Financial Economics, 105: 353 - 366.

Canton, E., Grilo, I., Monteagudo, J., Zwan, P. V. D. (2013) Perceived Credit Constraints in the European Union. Small Business Economics, Vol. 41, pp. 710 - 715.

CFO. (2013) Risk manažment: najväčšie riziká, ktorým čelia európske firmy. [online].[cit. 25. 02. 2013]. Retrieved from: http://www.cfo.sk/articles/risk-manazment-najvacsie-rizikaktorym-celia-europske-firmy\#.UjbZIMZM-Qo

Covaci, B. (2008) Credit Risk in Financing SME in Romania. Bucharest: Spiru Haret University. Retrieved from http://papers.ssrn.com/sol3/papers.cfm?abstract_id=1313879 (referred on 20/11/2013).

Dierkes, M., Erner, C., Langer, T., Norden, L. (2013) Business credit information sparing and default risk of private firms. Journal of Banking \& Finance 37: 2867 - 2878.

Di Giuli, A., Caselli, S., Gatti, S. (2011) Are small family firms financially sophisticated? Journal of Banking \& Finance, 35: 2931 - 2944.

Evropská komise. (2011) Velké záměry pro malé podniky-co dělá EU pro MSP. Lucemburk: Úřad pro publikace EU.

Fetisovová, E. et al. (2012) Aktuálne problémy financii malých a stredných podnikov. Bratislava: Ekonóm.

Fetisovová, E., Vlachynský, K., Sirotka, V. (2004) Financie malých a stredných podnikov. Bratislava: Ekonómia.

Fidrmuc, J., Hainz, C. (2010) Default Rates in The Loan Market for SMEs Evidence From Slovakia. Economic system, Vol. 34, pp. 133 - 147.

Geršl, A., Jakubík, P. 2012 Modely bankovního financování českých podniků a úvěrové riziko. Praha: Česká Národní Banka.

Henderson, J., Weiler, S. (2010) Entrepreneurs and job growth: probing the boundaries of time and space. Economic Development Quarterly, 24(1): 23 - 32. 
Hnilica, J., Fotr, J. (2009) Aplikovaná analýza rizika ve finančním managementu a investičním rozhodování. Praha: Grada.

Karpak, B., Topcu, I. (2010) Small medium manufacturing enterprises in Turkey: an analytic network process framework for prioritizing factors affecting success. International Journal of Production Economics, 125: 60 - 70.

Kirschenbaum, K., Norden, L. (2012) The Relationship between Borrower Risk and Loan Maturity in Small Business Lending. Journal of Business Finance \& Accounting, Vol. 39, Issue 5-6, pp. $730-757$.

Neuberger, D., Räthke, S. (2009) Microenterproses and multiple relationships: The case of professionals. Small Business Economics, Vol. 32, pp. 207 - 229.

Podnikatel'ská aliancia Slovenska. (2012). Podnikatel'ské prostredie sa zhoršuje. Retrieved from //http://spravy.pravda.sk/ekonomika/clanok/199136-pas-podnikatelske prostredie-sa- nadalejzhorsuje/

Psillaki, M., Tsolas, I. E. and Margaritis, D. (2010) Evaluation of Credit Risk Based on Firm Performance. European Journal of Operational Research, Vol. 201(3): 873 - 881.

Řezánková, H. (2007) Analýza dat z dotazníkových šetření. 1. vyd. Praha: Professional Publishing.

Risk management guide for small business. (2005) [online]. [cit. 28.03.2014]. Retrieved from:http://www.significanceinternational.com/Portals/ 0/Documents/2005-sme-risk management-guide-global-risk-alliance-nsw-dsrd.pdf

Riziká podnikania. (2013) Hlavné nevýhody a riziká podnikania. Retrieved from: http://msponline.sk/content/hlavne-nevyhody-rizika-podnikania

Slovenská obchodná a priemyselná komora. (2014). Firmy vnímajú podnikatel'ské prostredie na Slovensku negatívne. Bratislava: SOPK.

http://www.socscistatistics.com/tests/chisquare2/Default2.aspx

http://www.socscistatistics.com/tests/ztest/Default2.aspx. 